\author{
Economics Working Paper Series
}

2017/033

\title{
A Fine Collection: The Political Budget Cycle of Traffic Enforcement
}

\author{
Emanuele Bracco \\ The Department of Economics \\ Lancaster University Management School \\ Lancaster LA1 4YX \\ UK \\ (C) Authors \\ All rights reserved. Short sections of text, not to exceed \\ two paragraphs, may be quoted without explicit permission, \\ provided that full acknowledgement is given.
}




\title{
A Fine Collection: The Political Budget CyCle of Traffic Enforcement*
}

\author{
Emanuele Bracco ${ }^{\dagger}$
}

December 6, 2017

\begin{abstract}
With data from 1998 to 2015, we find evidence that before elections Italian mayors issue fewer tickets and collect a lower proportion of issued fines. This provides evidence that mayors strategically use both tax setting and collection to affect elections.
\end{abstract}

JEL classification: D72, H26, H71.

Keywords: Political Budget Cycle, parking tickets, tax collection.

*I thank Vincent O'Sullivan, Alessandro Santoro and an anonymous referee. All errors are my own.

${ }^{\dagger}$ Department of Economics, Lancaster University Management School, LA1 4XY, Lancaster, United Kingdom. Email: e.bracco@lancaster.ac.uk 


\section{Introduction}

Traffic enforcement tickets are a common source of revenues for local governments. They are a cheap way to raise funds with no necessity to touch existing tax policies, they are imposed on subjects who may not be resident (voters) in that particular area. Moreover, traffic regulations are often set by the same subjects issuing fines, with obvious scope for strategic behaviour: a speed camera can be easily switched on or off, irregular parking can be enforced very strictly or very laxly, parking regulations can be changed. Unlike taxes (such as property tax) or service charges (such as nursery school fees) traffic fines have further advantages: they are (mostly) unrelated to any "service" provided by the local government, have a near-zero marginal cost, and are issued to subjects who have breached a law or regulation, something that can be felt as "wrong", and that is generally avoidable. All these elements make traffic fines a very flexible and interesting policy instrument.

In Italy municipal governments issue about 20 million tickets per year; this amount does not include tickets issued by the national police forces, or outside urban areas; about $15 \%$ of non-tax revenues of municipalities comes from this source (source: our elaboration from municipal budgets). A further peculiarity makes our data quite unique: municipal budgets report both the cash-based and the accrual-based figures, allowing to distinguishing (for example) between mayors issuing fewer fines or collecting less effectively. Data from municipal budgets show that about $75 \%$ of accrued traffic-fine revenues are ever cashed in. The remaining quarter is not collected for a variety of reasons: fines resulting from traffic-enforcement cameras need to be notified within a given time frame to be valid, appeals are so frequent (and the full number of them is unknown) that municipalities choose not to show up in Court to defend each (small) claim ${ }^{1}$, municipalities may more generically be inefficient or ineffective in collecting (e.g. in case the car owner is not to be found, has no funds or just does not pay); anecdotally, it is also known that the central-government collection agency (Equitalia) - to which most municipalities entrust the collection of unpaid claims - is less efficient when collecting small amounts, while is more efficient for larger unpaid sums (originated by VAT, income or property tax evasion).

As a first instance the aim of this paper is to seek evidence on the political budget cycle of traffic fines, exploring both their issuance and collection. Secondly, but most importantly, through this exercise we also find evidence of a political budget cycle in the collection mechanism.

\footnotetext{
${ }^{1}$ In large municipalities, such as Milan, one can find also dedicated websites offering to file the appeal on your behalf for a small fee, claiming up to $97 \%$ success rate.
} 
This paper contributes to a number of strands of literature. First of all, it directly relates to the large literature on political budget cycle, started by Nordhaus (1975) and Rogoff (1990) and reviewed extensively by Dubois (2016). This literature highlights how nearly any aspect of public policy (expenditure levels and composition, taxation, deficit, public employment) are affected by electoral incentives, and in particular how these incentives are affecting policy choices more strongly when elections are closer (so in the pre-election period) or tighter (in marginal localities, in absence of term limits).

This paper also relates to the large literature on tax evasion. In particular the literature has highlighted how the decision to evade taxes depends on the beliefs held about the enforcement mechanism (see for example the seminal paper by Allingham and Sandmo (1972) and the review by Andreoni et al. (1998)): the decision of not paying a parking ticket (or the decision to file a "frivolous" appeal) can be equated to the decision to evade taxes, and related to the expectation of being chased for that payment.

Finally, this paper is also linked with a smaller number of works on traffic enforcement and policing: the famous paper by Fisman and Miguel (2007) found that diplomats from low social capital countries were less likely to pay traffic fines in New York; Garrett and Wagner (2009) noted how traffic fines are used more intensely by localities with tighter budgets; Guillamón et al. (2013) find evidence of a political budget cycle of police expenditure in Spanish municipalities.

\section{Institutional Background and Data}

Italy is subdivided into over 8,000 municipalities, ruled by directly elected mayors (for further institutional details see Bracco et al. (2015)). Each municipality follows its own electoral cycle, so that each year - typically in Spring - a number of municipalities goes to elections. Municipalities are in charge of a number of local services, including traffic management, and have substantial powers in revenue setting. Many municipalities - the exception being the smaller ones - have a municipal police force, which is directly dependent from the mayor, and is in charge of traffic controls, assisting bailiffs, checking on street sellers, and patrolling the territory. Since 1997-through a quite non-linear process, laden with legal challengesthe task of issuing parking tickets have been extended from members of the police forces to ad-hoc traffic wardens. In past two decades, an increasing amount of traffic enforcement cameras have been installed; resident-permit and pay-and-display parking have become more and more common also outside of major cities.

Municipalities' receive grants from upper-tier governments (mainly central government) 
and also have their own sources of revenues. On average one quarter of revenues come from fiscal sources (such as property tax, or income tax surcharges), one half from intergovernmental grants, and one quarter from non-tax sources (such as user charges, fees, and fines; see Bracco et al. (2013) for details).

Our dataset comprises municipal budgets and demographic and economic variables from 1998 to 2015, and electoral data for all mayors in power in that period (i.e. for elections held from 1994 onwards) $)^{2}$

As dependent variable we use figures related to traffic fines ("Municipal Police: HighwayCode Earmarked Resources"). In particular we measure (1) accrual figure (related to issued fines), (2) cashing of fines issued in the year, (3) the "collection index" calculated as a ratio between (2) and (1). Our main variables of interest are a "pre-election" dummy — which takes value 1 in the year of and before municipal elections are held—, a "marginal" dummy — which takes value 1 if the incumbent mayor has been elected with a margin of victory smaller than $5 \%$ - and a term-limit dummy - which takes value 1 if the incumbent mayor is barred from seeking re-election. ${ }^{3}$ These three variables are the typical variables used to isolate situations in which electoral incentives are particularly strong (once again, see Dubois (2016)).

We add a number control variables which are generally thought to affect local public finance outcomes: resident population (and its square), average declared taxable income, social capital (measured through turnout at European Parliament elections at the municipality level). We also add political controls such as dummies for left- and right-wing mayors (the residual category being unaffiliated mayors). We then include the share of revenues coming from intergovernmental grants and taxes, to control for vertical imbalances and fiscal autonomy. Finally, we control for two variables, which are more closely related to the "production function" of traffic fines: the number of city policemen (per hundred thousand inhabs.) and the number of registered vehicles (per thousand inhabs.). Our analysis excludes municipalities from Special Autonomy regions because of data availability; to exclude outliers, reporting errors, and municipalities with no traffic enforcement personnel, we also drop the first and last percentile of our dependent variables, and municipalities which do not show any revenue from traffic fines. Descriptive statistics are reported in Table 1.

\footnotetext{
${ }^{2}$ Municipal budgets (including data on number of fines issued and number of city policemen) and electoral data are made public by the Interior Ministry. Demographic data is provided by the Italian statistical office ISTAT. Data on taxable income is provided by the Finance Ministry. Data on number of registered vehicles is provided by ACI (Automobile Club d'Italia).

${ }^{3}$ Mayors in Italy are subject to a two (consecutive) term limit.
} 


\section{Empirical Strategy and Results}

We perform the following OLS regression, and show the results in Tables 2-3.

The specification can be written as:

$$
y_{i t}=\alpha+\beta P B C_{i t}+\gamma X_{i t}+p_{p}+\tau_{t}+\varepsilon_{i t}
$$

where $y$ is in turn the amount of fines issued, the amount of fines cashed in and a "collection index", calculated as the ratio between cashed and issued for municipality $i$ in year $t$. We focus on the coefficient $\beta$, i.e. the effect of electoral incentives on traffic fines figures. In our main table (Table 2), we show the results of regressions in which $P B C$ is a pre-election dummy, which takes value one in the year of the election and the year before that. We expect the effect of $P B C$ for each of the three dependent variables. We also include a battery of controls (as spelled out in the previous section), province and year fixed effects. Robust standard errors are clustered at the municipality level.

The results confirm our hypothesis: all three of our political budget cycle variables in Table 2 have the expected negative sign.

We cannot say if mayors issue fewer fines in the pre-election period, albeit the point estimate is negative (Column 1). We can instead state that mayors collect on average 18 Eurocent less per capita (Column 2), and exhibit a collection index which is $1.1 \%$ smaller.

Our control variables also give us interesting results, even if the presence of fixed effects and the fact that our regressions treats equally larger and smaller localities call for caution in the interpretation. Fines are used more intensely by larger and richer municipalities, municipalities receiving fewer grants, and raising fewer taxes. ${ }^{4}$ Social capital is non significant, but as we include province fixed effects, this is not particularly surprising.

These results are qualitatively confirmed using two alternative measures of $P B C$, shown in Table 3: dummies for mayors elected with a small margin (Columns 1, 3, 5), and termlimit dummies (Columns 2, 4, 6). The expectation is that the point estimates are negative for marginally elected mayors and positive for mayors subject to a term limit.

Mayors who have been elected with a small margin issue on average 89 Eurocent less in fines, and collect on average 52 Eurocent less. The collection index is about $1 \%$ smaller (albeit we can state this with only $90 \%$ confidence). The effect of term limit is positive, as expected, but fails to be significant at conventional levels.

\footnotetext{
${ }^{4}$ We are aware that taxes and traffic fines may be decided simultaneously by local governments. Our results are qualitatively unchanged if share of grants and taxes are omitted from the regressions. These results are available upon request.
} 
These results are robust to tweaking of the definition of the first two $P B C$ variables, e.g. defining as the pre-election dummy as only to do with the year of elections, or changing the definition of "marginal" as mayors elected with less that 10\% (as opposed to 5\%) margin (available upon request).

All in all, we have strong and robust evidence that the political budget cycle is very present in Italian municipalities, with mayors at the end of their term "slowing down" both the issuance, collection and collection rate of traffic fines. We have suggestive evidence that a similar dynamic happens with mayors elected with a small margin and (with opposite sign) mayors who are not seeking re-election.

Most importantly, though, we have shown that electoral incentives affect not only policy setting, but also policy enforcement, and more specifically revenue collection. The enforcement and collection mechanism needs to be fully included into political economy models, if one wants to uncover all potential sources of manipulation.

Table 1: Summary statistics

\begin{tabular}{lccc}
\hline \hline \multicolumn{1}{c}{ Variable } & Mean & Std. Dev. & N \\
\hline Tickets: Issued & 10.808 & 18.09 & 60477 \\
Tickets: Cashed & 7.086 & 12.577 & 60477 \\
Tickets: Index & 0.727 & 0.313 & 60477 \\
\hline Marginal & 0.16 & 0.366 & 60477 \\
Pre-election & 0.421 & 0.494 & 60477 \\
Term limit & 0.309 & 0.462 & 60477 \\
\hline Population, k & 9.508 & 33.042 & 60477 \\
Population, sq. & 1182.156 & 30144.406 & 60477 \\
Taxable income, pc. & 16.676 & 4.244 & 51262 \\
Social capital & 72.602 & 11.049 & 60441 \\
\hline Left-wing & 0.213 & 0.409 & 60477 \\
Right-wing & 0.125 & 0.33 & 60477 \\
Grants, share & 53.15 & 17.653 & 56855 \\
Tax revenues, share & 25.503 & 17.381 & 56855 \\
Munic. Policemen per 100k inahbs. & 0.01 & 0.237 & 57794 \\
Vehicles per thousand inhabs. & 596.422 & 74.235 & 59825 \\
\hline
\end{tabular}


Table 2: Effect of Electoral Incentives on Issuance and Collection of Traffic Fines (Pre-election dummy).

\begin{tabular}{lccc}
\hline \hline & $(1)$ & $(2)$ & $(3)$ \\
& Issued & Cashed & Index \\
& $\mathrm{b} / \mathrm{se}$ & $\mathrm{b} / \mathrm{se}$ & $\mathrm{b} / \mathrm{se}$ \\
\hline Pre-election & -0.108 & $-0.184^{* *}$ & $-0.011^{* * *}$ \\
& $(0.122)$ & $(0.082)$ & $(0.002)$ \\
\hline Population, k & $0.132^{* * *}$ & $0.077^{* * *}$ & -0.000 \\
& $(0.016)$ & $(0.011)$ & $(0.000)$ \\
Population, sq. & $-0.000^{* * *}$ & $-0.000^{* * *}$ & 0.000 \\
& $(0.000)$ & $(0.000)$ & $(0.000)$ \\
Social capital & -0.033 & $-0.027^{*}$ & -0.000 \\
& $(0.023)$ & $(0.015)$ & $(0.000)$ \\
Taxable income, pc. & $0.838^{* * *}$ & $0.630^{* * *}$ & $-0.003^{* *}$ \\
& $(0.113)$ & $(0.076)$ & $(0.001)$ \\
\hline Left-wing & -0.362 & 0.002 & -0.004 \\
& $(0.400)$ & $(0.276)$ & $(0.006)$ \\
Right-wing & 0.707 & 0.449 & $-0.015^{* *}$ \\
Grants, share & $(0.450)$ & $(0.296)$ & $(0.007)$ \\
& $-0.237^{* * *}$ & $-0.144^{* * *}$ & 0.000 \\
Tax revenues, share & $(0.019)$ & $(0.012)$ & $(0.000)$ \\
& $-0.263^{* * *}$ & $-0.160^{* * *}$ & $0.001^{* * *}$ \\
Munic. Policemen & $(0.019)$ & $(0.012)$ & $(0.000)$ \\
& 0.423 & 0.276 & 0.003 \\
Vehicles & $(0.504)$ & $(0.288)$ & $(0.003)$ \\
& 0.001 & -0.002 & $-0.000^{* *}$ \\
Constant & $(0.003)$ & $(0.002)$ & $(0.000)$ \\
& $17.299^{* * *}$ & $11.113^{* * *}$ & $0.883^{* * *}$ \\
\hline N & $(3.016)$ & $(1.898)$ & $(0.040)$ \\
r2 & 44735 & 43179 & 43287 \\
\hline \hline$* p<0.1 * * p<0.05, * * * p<0.01$ & & 0.045 \\
\hline & 0.158 & 0.161 & \\
& & & \\
& & & \\
& &
\end{tabular}

$* p<0.1, * * p<0.05, * * * p<0.01$

Note: Panel data with province and year fixed effects.

Standard errors clustered at the municipality levels.

All regressions include controls.

Table 3: Effect of Electoral Incentives on Issuance and Collection of Traffic Fines (Marginal and Term limit dummies).

\begin{tabular}{|c|c|c|c|c|c|c|}
\hline & (1) & (2) & (3) & (4) & (5) & (6) \\
\hline & \multicolumn{2}{|c|}{ Issued } & \multicolumn{2}{|c|}{ Cashed } & \multicolumn{2}{|c|}{ Index } \\
\hline & $\mathrm{b} / \mathrm{se}$ & $\mathrm{b} / \mathrm{se}$ & $\mathrm{b} / \mathrm{se}$ & $\mathrm{b} / \mathrm{se}$ & $\mathrm{b} / \mathrm{se}$ & $\mathrm{b} / \mathrm{se}$ \\
\hline Marginal & $\begin{array}{c}-0.891^{* * *} \\
(0.325)\end{array}$ & & $\begin{array}{c}-0.520^{* *} \\
(0.221)\end{array}$ & & $\begin{array}{l}-0.009^{*} \\
(0.005)\end{array}$ & \\
\hline Term limit & & $\begin{array}{c}0.211 \\
(0.233)\end{array}$ & & $\begin{array}{c}0.095 \\
(0.159)\end{array}$ & & $\begin{array}{c}0.002 \\
(0.004)\end{array}$ \\
\hline $\mathrm{N}$ & 44735 & 44735 & 43179 & 43179 & 43287 & 43287 \\
\hline r2 & 0.158 & 0.158 & 0.161 & 0.161 & 0.045 & 0.045 \\
\hline
\end{tabular}

$* p<0.1, * * p<0.05, * * * p<0.01$
Note: Panel data with province and year fixed effects. Standard errors clustered at the municipality levels. All regressions include controls. 


\section{Acknowledgement}

This research did not receive any specific grant from funding agencies in the public, commercial, or not-for-profit sectors. 


\section{References}

Allingham, M. G. and A. Sandmo (1972). Income tax evasion: a theoretical analysis. Journal of Public Economics 1(3-4), 323-338.

Andreoni, J., B. Erard, and J. Feinstein (1998). Tax compliance. Journal of Economic Literature 36(2), 818-860.

Bracco, E., M. De Paola, and C. Green (2015). Long lasting differences in civic capital: Evidence from a unique immigration event in Italy. Journal of Economic Behavior 83 Organization 120(C), 160-173.

Bracco, E., B. Lockwood, F. Porcelli, and M. Redoano (2015). Intergovernmental grants as signals and the alignment effect: Theory and evidence. Journal of Public Economics 123(C), 78-91.

Bracco, E., F. Porcelli, and M. Redoano (2013). Political Competition, Tax Salience and Accountability: Theory and Some Evidence from Italy. Technical report.

Dubois, E. (2016, Jan). Political business cycles 40 years after nordhaus. Public Choice 166(1), 235-259.

Fisman, R. and E. Miguel (2007, December). Corruption, Norms, and Legal Enforcement: Evidence from Diplomatic Parking Tickets. Journal of Political Economy 115(6), 10201048.

Garrett, T. A. and G. A. Wagner (2009, 02). Red Ink in the Rearview Mirror: Local Fiscal Conditions and the Issuance of Traffic Tickets. Journal of Law and Economics 52(1), 71-90.

Guillamón, M., F. Bastida, and B. Benito (2013, December). The electoral budget cycle on municipal police expenditure. European Journal of Law and Economics 36(3), 447-469.

Nordhaus, W. D. (1975). The political business cycle. The Review of Economic Studies 42(2), $169-190$.

Rogoff, K. (1990, March). Equilibrium Political Budget Cycles. American Economic Review $80(1), 21-36$. 